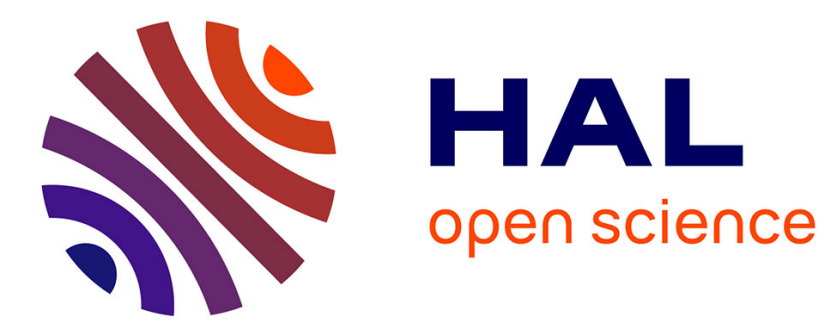

\title{
Optimizing carbon/carbon supercapacitors in aqueous alkali sulfates electrolytes \\ Qiang Gao
}

\section{To cite this version:}

Qiang Gao. Optimizing carbon/carbon supercapacitors in aqueous alkali sulfates electrolytes. Journal of Energy Chemistry, 2019, 38, pp.219 - 224. 10.1016/j.jechem.2019.03.037 . hal-03486289

\section{HAL Id: hal-03486289 \\ https://hal.science/hal-03486289}

Submitted on 20 Dec 2021

HAL is a multi-disciplinary open access archive for the deposit and dissemination of scientific research documents, whether they are published or not. The documents may come from teaching and research institutions in France or abroad, or from public or private research centers.
L'archive ouverte pluridisciplinaire HAL, est destinée au dépôt et à la diffusion de documents scientifiques de niveau recherche, publiés ou non, émanant des établissements d'enseignement et de recherche français ou étrangers, des laboratoires publics ou privés.

\section{다)(1) $(5$}

Distributed under a Creative Commons Attribution - NonCommercial| 4.0 International 


\title{
Optimizing carbon/carbon supercapacitors in aqueous alkali sulfates electrolytes
}

\author{
Qiang $\mathrm{Gao}^{\mathrm{a}, \mathrm{b}, *}$ \\ ${ }^{a} I C M N-U M R$ 7374, CNRS-University of Orleans, $1 \mathrm{~b}$ rue de la Ferollerie, CS 40059 \\ 45071 Orléans cedex, France \\ ${ }^{\mathrm{b}}$ Scanning Probe Microscopy Group, Center for Nanophase Materials Sciences, Oak Ridge National \\ Laboratory, P.O. Box 2008, Oak Ridge, TN 37831, USA \\ *Corresponding author. E-mail address : gaoq@ornl.gov (Q. Gao).
}

\begin{abstract}
Neutral aqueous alkali sulfate has shown great interests for developing environmentally friendly high voltage and high energy supercapacitors. This work focuses on systematically investigating the properties of symmetric carbon/carbon supercapacitors in neutral aqueous alkali sulfates. At room temperature, the largest power and energy density were obtained with $\mathrm{K}_{2} \mathrm{SO}_{4}$ electrolyte due to the smallest cation dimensions and highest electrical conductivity. At low temperature, aqueous $\mathrm{Li}_{2} \mathrm{SO}_{4}$ electrolyte presents the best performance due to the largest solubility, allowing a long-term stability at temperatures ranging between $20{ }^{\circ} \mathrm{C}$ and $-10{ }^{\circ} \mathrm{C}$ at a maximum voltage of $1.8 \mathrm{~V}$. The excellent stability has been confirmed that capacitance retention achieves as high as $92 \%$ after 10,000 cycles. The capacitance variations with temperatures could essentially result from kinetic diffusion barrier, ion dimension changes and fewer pseudo-capacitance contributions under different temperatures. This work highlights the selected virtues of different alkali sulfate electrolytes for enhanced supercapacitors.
\end{abstract}

Keywords Supercapacitor; Alkali sulfates electrolyte; Carbon; Temperature dependence 


\section{Introduction}

Enhancing energy density while keeping eco-friendly systems remains the primary challenge facing supercapacitors developers. This improvement can be easily realized by expanding the cell voltage since the energy stored is proportional to its square $[1,2]$. The voltage depends on the stability potential window of the electrolyte over a given electrode material [3]. In aqueous $\mathrm{KOH}$ or $\mathrm{H}_{2} \mathrm{SO}_{4}$, the operational voltage when using carbons electrodes is usually less than $1.0 \mathrm{~V}$, whereas it is in the range of 2.5-2.7 $\mathrm{V}$ for organic electrolytes [4, 5]. Unfortunately, the latter present serious drawbacks, such as low conductivity, moisture isolated building atmosphere and they are mainly prepared using environment unfriendly solvents as acetonitrile. Thus, aqueous electrolytes could be more attractive for supercapacitor industry when assembling with such electrolytes would reach the comparable energy density than the ones using organic electrolytes [6].

Lately, neutral aqueous electrolytes have been shown as a very promising alternative. For instance, the stability potential window of $0.5 \mathrm{~mol} \mathrm{~L}^{-1} \mathrm{Na}_{2} \mathrm{SO}_{4}$ solution over a porous carbon electrode can reach $2.0 \mathrm{~V}$ or even more $[7,8]$. Actually, it has been observed that the $\mathrm{H}_{2}$ overpotential is higher in neutral aqueous electrolytes than in aqueous $\mathrm{KOH}$ or $\mathrm{H}_{2} \mathrm{SO}_{4}$ [9]. Consequently, a practical voltage of $1.6 \mathrm{~V}$ during 10,000 charge/discharge cycles has been obtained with a symmetric carbon/carbon capacitor in aqueous $\mathrm{Na}_{2} \mathrm{SO}_{4}$ [8]. Even higher voltage of $2.2 \mathrm{~V}$ has been claimed when using $1 \mathrm{~mol} \mathrm{~L}^{-1} \mathrm{Li}_{2} \mathrm{SO}_{4}$ [10]. The reason announced for $2.2 \mathrm{~V}$ was the high hydration energy and that the equilibrium between protons and hydroxyl groups do not favor hydrogen or oxygen evolution due to the neutral-pH character in alkali sulfates solutions. According to Gao's results [11], the maximum cell voltage is essentially restricted by the positive electrode; when the positive electrode potential is too high, it leads to irreversible electro-oxidation on the active sites of the carbon electrode. A controlled chemical oxidation of carbon with hydrogen peroxide can help to push the maximum potential of the positive electrode to slightly lower values and by this way allows the maximum voltage to be slightly increased. Online electrochemical mass spectroscopy revealed 
that the activated carbon electrode in aqueous $\mathrm{Li}_{2} \mathrm{SO}_{4}$ is oxidized already at $0.6 \mathrm{~V}$ with the evolution of minor amount of $\mathrm{CO}$ and $\mathrm{CO}_{2}$ [12]. Overall, the use of alkali sulfates as electrolytes not only eliminates the disadvantages related to corrosion in aqueous electrolytes, but also it gives an opportunity to realize high energy density supercapacitors being eco-friendly, cost effective and safe. However, further research works should be carried out in these media to realize supercapacitors with optimized performance. In fact, the main disadvantage of aqueous electrolytes is the "high" freezing point of water which might limit the operating temperature range [13]. However, low temperature operation of supercapacitors is mandatory for specific applications such as cold-starting in automotive [14]. In this work, we focus on investigating systematically different alkali sulfates, i.e., $\mathrm{Li}_{2} \mathrm{SO}_{4}, \mathrm{Na}_{2} \mathrm{SO}_{4}$, and $\mathrm{K}_{2} \mathrm{SO}_{4}$, as electrolytes in symmetric carbon/carbon capacitors. Moreover, electrochemical impedance spectroscopy (EIS) has been employed to analyze the ion diffusion behaviors in the electrolytes. We explored temperatures influence for electrochemical performance by picking $-10{ }^{\circ} \mathrm{C}$ and $20{ }^{\circ} \mathrm{C}$ as two examples. The results will show that $2 \mathrm{~mol} \mathrm{~L}^{-1} \mathrm{Li}_{2} \mathrm{SO}_{4}$ is the best electrolyte for an optimum performance in the realization of low temperature operation.

\section{Experimental}

As electrode active material, a highly micro-porous activated carbon (AC, MeadWestvaco Co., USA) with a specific surface area of $2244 \mathrm{~m}^{2} \mathrm{~g}^{-1}$ and small surface oxygen content i.e. 2.4 at\% has been used. A more detailed characterization can be found elsewhere [8]. Pellet-type electrodes $(1 \mathrm{~cm}$ diameter) were prepared by pressing a mixture of AC (80 wt \%), acetylene black (10 wt $\%$, pure black, Superior Graphite Co., USA), and PTFE (10 wt\%, Aldrich) as binder. Electrochemical characterization has been carried out in three- and two-electrode cells by using cyclic voltammetry ( 2 $\left.\mathrm{mV} \mathrm{s}^{-1}\right)$ and galvanostatic charge/discharge cycling $\left(0.2\right.$ to $\left.10 \mathrm{~A} \mathrm{~g}^{-1}\right)$ with a VMP2 multichannel potentiostat/galvanostat (Bio-Logic, France). The electrolytes used were 0.5 and $2 \mathrm{~mol} \mathrm{~L}^{-1} \mathrm{Li}_{2} \mathrm{SO}_{4}$, $0.5 \mathrm{~mol} \mathrm{~L}^{-1} \mathrm{Na}_{2} \mathrm{SO}_{4}$ and $0.5 \mathrm{~mol} \mathrm{~L}^{-1} \mathrm{~K}_{2} \mathrm{SO}_{4}$. Three-electrode cells were assembled by using a carbonbased pellet stuck onto a gold current collector with a graphite conductive adhesive 502 (13 wt\%, 
Electron Microscopy Sciences Company, UK) as working electrode, $\mathrm{Hg} / \mathrm{Hg}_{2} \mathrm{SO}_{4}$ as reference electrode and a graphite rod as counter electrode. All potential values are expressed vs. normal hydrogen electrode (NHE). Two-electrode Teflon Swagelok ${ }^{\circledR}$ cells were assembled with the carbon electrodes over gold current collectors separated by a glass fiber separator. The supercapacitor gravimetric capacitance in farads per gram $\left(\mathrm{F} \mathrm{g}^{-1}\right)$ was calculated from the galvanostatic charge/discharge cycling at a current density of $200 \mathrm{~mA} \mathrm{~g}^{-1}$ by using the Formula (1):

$$
C=(2) I /\left[(\mathrm{d} V / \mathrm{d} t) m_{\mathrm{e}}\right]
$$

where $I$ is the current (A), $\mathrm{d} V / \mathrm{d} t$ is the slope of the discharge curve $\left(\mathrm{V} \mathrm{s}^{-1}\right), m_{\mathrm{e}}$ is the mass of electrode (g). Electrochemical impedance spectroscopy (EIS) was realized over the symmetric twoelectrode capacitors using a VMP2 multi-channel generator (Bio-Logic, France). To acquire the AC impedance spectra at $0 \mathrm{~V}$, amplitude of $10 \mathrm{mV}$ was applied in the frequency range of $100 \mathrm{kHz}$ to $0.01 \mathrm{~Hz}$. Before starting the frequency scan, the capacitors were subjected to soaking at the applied potential of $0 \mathrm{~V}$ to stabilize the current.

\section{Results and discussion}

The stability potential window of different aqueous alkali sulfate-based electrolytes over the AC carbon has been firstly investigated using a three-electrode cell. For comparison purposes, $\mathrm{Li}_{2} \mathrm{SO}_{4}$, $\mathrm{Na}_{2} \mathrm{SO}_{4}$, and $\mathrm{K}_{2} \mathrm{SO}_{4}$ solutions have been prepared with the same concentration, i.e. $0.5 \mathrm{~mol} \mathrm{~L}{ }^{-1}$. Fig. 1 shows the cyclic voltammograms $(\mathrm{CV})$ recorded with a gradual decrease of negative potential cutoff, i.e., towards $\mathrm{H}_{2}$ evolution (the theoretical values for water reduction are $-0.325,-0.378$, and $0.382 \mathrm{~V}$ vs. $\mathrm{NHE}$ for $0.5 \mathrm{~mol} \mathrm{~L}^{-1} \mathrm{Li}_{2} \mathrm{SO}_{4}, \mathrm{Na}_{2} \mathrm{SO}_{4}$, and $\mathrm{K}_{2} \mathrm{SO}_{4}$, respectively). The maximum positive potential has been set at a value slightly lower than the theoretical one for $\mathrm{O}_{2}$ evolution. The $\mathrm{CV}$ curves present quite similar in all three electrolytes. If the negative potential cut-off is higher than the value for water reduction, a rectangular shaped $\mathrm{CV}$, typical of the electrical double-layer (EDL) charging, is obtained. When it becomes lower than theoretical reduction potential values, water is 
reduced, and the EDL formation takes place together with a pseudo-capacitive contribution related to electrochemically reversible sorption of nascent hydrogen inside the pores of activated carbon $[9,15$, 16]. A noticeable hump appears around $0.4-0.5 \mathrm{~V}$ vs. NHE during the anodic sweep, owing to the electro-oxidation process of the stored hydrogen [11]. Pseudo-capacitance from reversible hydrogen storage might contribute effectively to the total capacitance in addition to the EDL capacitance. The negative current increases sharply from potentials below $-1.0 \mathrm{~V}$ vs. NHE, indicating $\mathrm{H}_{2}$ gas evolution and the plausible limit for negative polarization. Finally, we can estimate that the stability potential window of the $\mathrm{AC}$ carbon in $0.5 \mathrm{~mol} \mathrm{~L}^{-1} \mathrm{Li}_{2} \mathrm{SO}_{4}$ and $\mathrm{K}_{2} \mathrm{SO}_{4}$ is around $2.0 \mathrm{~V}$, as it was previously found for the same carbon material in $0.5 \mathrm{~mol} \mathrm{~L}^{-1} \mathrm{Na}_{2} \mathrm{SO}_{4}[7,8]$ (also included in Fig. 1). However, the specific capacitance of symmetric AC/AC supercapacitors depends on the electrolyte used. The values calculated from galvanostatic charge/discharge at $200 \mathrm{~mA} \mathrm{~g}^{-1}$ are 98,109 , and 129 $\mathrm{F} \mathrm{g}^{-1}$ for $0.5 \mathrm{~mol} \mathrm{~L} \mathrm{Li}_{2} \mathrm{SO}_{4}, \mathrm{Na}_{2} \mathrm{SO}_{4}$, and $\mathrm{K}_{2} \mathrm{SO}_{4}$ based supercapacitors, respectively. Such results indicate that the capacitance increases with the decrease of the hydrated cation size, i.e., $\mathrm{Li}^{+}$(3.81 Á) $\left.>\mathrm{Na}^{+}(3.59 \AA ̊)\right)>\mathrm{K}^{+}(3.34$ Á) (see Table 1$)$.

Such differences are further confirmed by electrochemical impedance spectroscopy (EIS) which provides the resistance and capacitance of a supercapacitor from the frequency response [17-19]. Generally, a supercapacitor behaves like a pure resistor at high frequencies and a capacitor at relatively low frequencies $[20,21]$. The Nyquist plots for the symmetric AC/AC capacitors using aqueous $0.5 \mathrm{~mol} \mathrm{~L}-1 \mathrm{Li}_{2} \mathrm{SO}_{4}, \mathrm{Na}_{2} \mathrm{SO}_{4}$ and $\mathrm{K}_{2} \mathrm{SO}_{4}$ as electrolytes are depicted in Fig. 2. The inset displays the expanded view in high frequency region of the same plot. As the construction of the three supercapacitors just differs on the electrolyte, the electrical series resistance (ESR) calculated from the intersection on the real axis of the Nyquist plot in the high frequency region should be mainly related to the bulk electrolyte conductivity [22]. The conductivity values of the three electrolytes measured at room temperature $\left(20{ }^{\circ} \mathrm{C}\right)$ are listed in Table 1 . As expected, the conductivity decreases when the size of the hydrated cation increased in the order $\mathrm{K}_{2} \mathrm{SO}_{4}>\mathrm{Na}_{2} \mathrm{SO}_{4}>$ 
$\mathrm{Li}_{2} \mathrm{SO}_{4}$ [23]. The inset of Fig. 1 confirms that the ESRs are inversely proportional to electrolyte conductivity. The equivalent distributed resistance (EDR), obtained with the linear projection from the vertical portion of the Nyquist plot to the real axis (Fig. 2), represents the ions diffusion through carbon pores. Table 1 shows that the EDR values vary inversely with the solvated cation radius of three electrolytes [24, 25]. Finally, one can conclude that the cation diffusion through carbon pores dominates the capacitance and resistance (EDR) of those supercapacitors [26]. The resistance differences found for the supercapacitors operating in the different electrolytes will influence their power density because of the inverse correlation between power and resistance. Ragone plots, which describe the relation between power density and energy density, have been further employed to highlight the effects of electrolytes on the system performance. As a practical voltage of $1.6 \mathrm{~V}$ has been demonstrated with symmetric AC/AC capacitors in $0.5 \mathrm{~mol} \mathrm{~L}^{-1} \mathrm{Na}_{2} \mathrm{SO}_{4}$ [8], Fig. 3 depicts the Ragone plots obtained with symmetric AC/AC capacitors, at such a voltage, using aqueous 0.5 mol $\mathrm{L}^{-1} \mathrm{Li}_{2} \mathrm{SO}_{4}, \mathrm{Na}_{2} \mathrm{SO}_{4}$, and $\mathrm{K}_{2} \mathrm{SO}_{4}$ as electrolytes. The energy and power extractable at $10 \mathrm{~s}$ discharge time (see straight line in Fig. 3) are the largest in $0.5 \mathrm{~mol} \mathrm{~L}^{-1} \mathrm{~K}_{2} \mathrm{SO}_{4}$. It confirms that the main contributions for system overall resistance is the EDR (Fig. 2) [25]. Regarding the energy density, $\mathrm{K}_{2} \mathrm{SO}_{4}$ presents the largest one because of the highest specific capacitance in this media. In conclusion, $\mathrm{K}_{2} \mathrm{SO}_{4}$ seems to be the best neutral aqueous electrolyte in terms of energy and power density at room temperature.

In practice, low temperature performance of supercapacitors plays a significant role for some specific applications. Nevertheless, low temperature operation can be a problem when using aqueous electrolytes in reason of water freezing point. However, such freezing point can be reduced by the presence of a salt and the extent of such depression depends on the concentration of the solution. In this sense, Table 2 summarizes the solubility of $\mathrm{Li}_{2} \mathrm{SO}_{4}, \mathrm{Na}_{2} \mathrm{SO}_{4}$ and $\mathrm{K}_{2} \mathrm{SO}_{4}$ at $0{ }^{\circ} \mathrm{C}$ and $25{ }^{\circ} \mathrm{C}$. Whereas the solubility of $\mathrm{K}_{2} \mathrm{SO}_{4}$ and $\mathrm{Na}_{2} \mathrm{SO}_{4}$ diminishes when decreasing temperature, it is not much modified for $\mathrm{Li}_{2} \mathrm{SO}_{4}$. As a consequence, the Nyquist plots (Fig. 4) show that at $-10{ }^{\circ} \mathrm{C}$ the $\mathrm{AC} / \mathrm{AC}$ 
supercapacitors based on $0.5 \mathrm{~mol} \mathrm{~L}^{-1} \mathrm{~K}_{2} \mathrm{SO}_{4}$ and $\mathrm{Na}_{2} \mathrm{SO}_{4}$ behave as resistors in which respective ESR extracted at $10 \mathrm{kHz}$ reaches 4025 and 4295 ohms. By contrasts, the supercapacitor using $0.5 \mathrm{~mol} \mathrm{~L}^{-1}$ $\mathrm{Li}_{2} \mathrm{SO}_{4}$, even if it presents a high resistance i.e. ESR of $72 \mathrm{ohm}$, has still some capacitive behavior.

As seen in Table 2, the solubility of $\mathrm{Li}_{2} \mathrm{SO}_{4}$ is considerably higher than that of the other alkali salts especially at low temperature. In such a way, by using $\mathrm{Li}_{2} \mathrm{SO}_{4}$, it is possible to prepare more concentrated electrolytes and also to have a higher freezing point depression. The supercapacitor using $2 \mathrm{~mol} \mathrm{~L}^{-1} \mathrm{Li}_{2} \mathrm{SO}_{4}$ presents a typical capacitive behavior with a relatively low resistance i.e. ESR of $1.5 \mathrm{ohm}$ at temperatures as low as $-10{ }^{\circ} \mathrm{C}$ (Fig. 4). In other words, the $2 \mathrm{~mol} \mathrm{~L}^{-1} \mathrm{Li}_{2} \mathrm{SO}_{4}$ solutions allow the freezing point of the electrolyte to be depressed, while keeping a good supercapacitor performance.

Since concentrated $\mathrm{Li}_{2} \mathrm{SO}_{4}$ seems to be the most promising aqueous electrolyte for being integrated into commercial devices, we have more extensively investigating the electrochemical performance in such electrolyte at different temperatures, i.e. $20^{\circ} \mathrm{C}$ and $-10^{\circ} \mathrm{C}$. Fig. 5 (a) depicts $\mathrm{CVs}$ obtained for the AC carbon in a three electrode cell with a gradual shift of potential cut-off to more negative values i.e., towards $\mathrm{H}_{2}$ evolution (the theoretical value of $20{ }^{\circ} \mathrm{C}$ is $-0.35 \mathrm{~V}$ vs. NHE in aqueous $2 \mathrm{~mol} \mathrm{~L}^{-1} \mathrm{Li}_{2} \mathrm{SO}_{4}$ ). The general aspect of the $\mathrm{CVs}$ is comparable to those which have been obtained when using $0.5 \mathrm{~mol} \mathrm{~L}^{-1} \mathrm{Li}_{2} \mathrm{SO}_{4}$ (Fig. 1b). The stability potential window of the $\mathrm{AC}$ carbon is around $2.0 \mathrm{~V}$, identical to the value found for the $0.5 \mathrm{~mol} \mathrm{~L}^{-1}$ one.

Fig. 5(b) depicts the CVs obtained with the three-electrode cell at $-10{ }^{\circ} \mathrm{C}$. The water reduction peak during the cathodic scan and its anodic counter-part are less noticeable at $-10{ }^{\circ} \mathrm{C}$ than at $20{ }^{\circ} \mathrm{C}$ [27], suggesting that more hydrogen was adsorbed into carbon porosity at higher temperatures. This fact fits well with the chemical character of the $\mathrm{C}-\mathrm{H}$ bond; in other words, the temperature increase impacts positively in decreasing the kinetic barrier for hydrogen adsorption/desorption processes [27]. With the increase of temperature from $-10{ }^{\circ} \mathrm{C}$ and $20{ }^{\circ} \mathrm{C}$, the oxidation potential decreases from ca. 0.6 to $0.45 \mathrm{~V}$ vs. NHE (Fig. 5). Consequently, the over-potential for hydrogen electro-oxidation is 
lower at room temperature than that of $-10{ }^{\circ} \mathrm{C}$. This decrease of the over-potential is directly related to the lower ohmic drop because of a higher conductivity of the solution at higher temperatures. Since more hydrogen was reversibly sorbed into carbons at higher temperatures and also is extracted at lower potential; it can be concluded that the pseudo-capacitive contribution to the total capacitance is larger in the case of $20{ }^{\circ} \mathrm{C}$ than that of $-10{ }^{\circ} \mathrm{C}$.

All the phenomena described above are also visible in the CVs recorded over symmetric AC/AC capacitors at $20{ }^{\circ} \mathrm{C}$ and $-10{ }^{\circ} \mathrm{C}$ (Fig. 6). When the working voltages are lower than $1.2 \mathrm{~V}$, pure capacitive behavior, typical rectangular shaped CVs, are obtained. More rectangular shaped CVs obtained at $20{ }^{\circ} \mathrm{C}$ than at $-10{ }^{\circ} \mathrm{C}$ indicates that $20{ }^{\circ} \mathrm{C}$ is more favorable for EDL formation at electrolyte/carbon interface. Slight derivation from typical rectangular shaped curves at $-10{ }^{\circ} \mathrm{C}$ reveals the larger resistance of system due to the viscosity increase and the conductivity decrease of lithium sulfate solutions with the temperature decrease. As a result, the specific capacitance at $1.2 \mathrm{~V}$ reaches 126 and $105 \mathrm{~F} \mathrm{~g} \mathrm{~g}^{-1}$ when operating at $20{ }^{\circ} \mathrm{C}$ and $-10{ }^{\circ} \mathrm{C}$, respectively. Furthermore, more noticeable oxidation and reduction peaks are observed at $20{ }^{\circ} \mathrm{C}$ than those at $-10{ }^{\circ} \mathrm{C}$ when working higher than $1.2 \mathrm{~V}$ (Fig. 6). As described above, the reason is that more hydrogen is stored into carbons at $20{ }^{\circ} \mathrm{C}$ than at $-10{ }^{\circ} \mathrm{C}$ leading to larger pseudo-capacitance. Consequently, the specific capacitance at $1.6 \mathrm{~V}$ achieves 137 and $116 \mathrm{~F} \mathrm{~g}^{-1}$ at 20 and $-10{ }^{\circ} \mathrm{C}$, respectively. The differences in capacitance obtained at cell voltages below $1.2 \mathrm{~V}$, when only pure capacitive behaviors present at 20 ${ }^{\circ} \mathrm{C}$ or $-10{ }^{\circ} \mathrm{C}$, can be further clarified by EIS (Fig. 7). The ESR values extracted at $10 \mathrm{kHz}$ show 0.61 and $1.50 \mathrm{ohm}$ for $20^{\circ} \mathrm{C}$ and $-10{ }^{\circ} \mathrm{C}$, respectively. The EDR values, relating with the diffusion of ions inside the pores of carbon, are 7.7 and $3.3 \mathrm{ohm}$ in terms of $-10{ }^{\circ} \mathrm{C}$ and $20{ }^{\circ} \mathrm{C}$. Down to $-10{ }^{\circ} \mathrm{C}$, it becomes difficult for the ions to move towards the Helmholtz plane and consequently delivers a decrease of EDL capacitance [28]. The lower kinetic energy obtained from a lower temperature reduces the free spaces between $\mathrm{Li}^{+} / \mathrm{SO}_{4}{ }^{2-}$ and water molecular. The activation energy for overcoming the diffusion resistance presents much higher than those of relatively higher 
temperatures as a proof of larger EDR and ESR values. The increase of diffusion resistance could be the reason for the capacitance decrease when temperature varies from $20{ }^{\circ} \mathrm{C}$ to $-10{ }^{\circ} \mathrm{C}$.

Long-term stability at $20{ }^{\circ} \mathrm{C}$ and $-10{ }^{\circ} \mathrm{C}$ has been evaluated with galvanostatic charge/discharge cycling at a relatively high current density of $1 \mathrm{~A} \mathrm{~g}^{-1}$ during 10,000 cycles (Fig. 8). At room temperature, the system shows a relatively good stability at $1.8 \mathrm{~V}$. At such a cell voltage, the capacitance slightly decreases during the initial 1, 000 cycles and then it keeps almost constant until 10,000 cycles. However, if the cell voltage is increased to $1.9 \mathrm{~V}$, a pronounced capacitance loss of $30 \%$ takes place after 10, 000 cycles. Down to $-10{ }^{\circ} \mathrm{C}$, Fig. 8 shows that even if the initial capacitance is around $20 \mathrm{~F} \mathrm{~g}^{-1}$ smaller than that at room temperature, after 10,000 cycles only $8 \%$ of capacitance is lost when operating at $1.8 \mathrm{~V}$, indicating lower corrosion involving than higher temperature of $20{ }^{\circ} \mathrm{C}$. It can be therefore concluded that $2 \mathrm{~mol} \mathrm{~L}^{-1} \mathrm{Li}_{2} \mathrm{SO}_{4}$ as electrolyte allows a long cycle operation at temperatures ranging between $20{ }^{\circ} \mathrm{C}$ and $-10{ }^{\circ} \mathrm{C}$ at a maximum voltage as high as $1.8 \mathrm{~V}$. Hence, among the three alkali sulfates investigated, lithium sulfate is the most interesting one since it remains highly soluble at relatively low temperatures allowing AC/AC capacitors to operate with good electrochemical performance at $-10{ }^{\circ} \mathrm{C}$ when using a $2 \mathrm{~mol} \mathrm{~L} \mathrm{~L}^{-1}$ solution.

\section{Conclusions}

Symmetric carbon/carbon capacitors with neutral aqueous alkali sulfates have been systematically investigated. At room temperature, the highest power and energy density were obtained when operating in $\mathrm{K}_{2} \mathrm{SO}_{4}$ due to the lowest ESR and EDR as a result of the smallest cation size and highest electrical conductivity, respectively, and of the higher capacitance. Actually, the order of capacitance was $0.5 \mathrm{~mol} \mathrm{~L}^{-1} \mathrm{Li}_{2} \mathrm{SO}_{4}<0.5 \mathrm{~mol} \mathrm{~L}^{-1} \mathrm{Na}_{2} \mathrm{SO}_{4}<0.5 \mathrm{~mol} \mathrm{~L}^{-1} \mathrm{~K}_{2} \mathrm{SO}_{4}$ as the sequence of hydrated cation size $\left(\mathrm{K}^{+}<\mathrm{Na}^{+}<\mathrm{Li}^{+}\right)$. At low temperature down to $-10{ }^{\circ} \mathrm{C}, \mathrm{Li}_{2} \mathrm{SO}_{4}$ based supercapacitors present the best performance. At $-10{ }^{\circ} \mathrm{C}$ and the same electrolyte concentration, $\mathrm{K}_{2} \mathrm{SO}_{4}$ and $\mathrm{Na}_{2} \mathrm{SO}_{4}$ based capacitors show pure resistive behaviors while $\mathrm{Li}_{2} \mathrm{SO}_{4}$ based one presents capacitive characteristics. Moreover, $\mathrm{Li}_{2} \mathrm{SO}_{4}$ presents as an advantage of a great solubility which 
enable high concentrated solutions. A solution of $2 \mathrm{~mol} \mathrm{~L}^{-1} \mathrm{Li}_{2} \mathrm{SO}_{4}$ allows a long cycle operation at temperatures ranging between $20^{\circ} \mathrm{C}$ and $-10{ }^{\circ} \mathrm{C}$ at a cell voltage as high as $1.8 \mathrm{~V}$. Therefore, the use of alkali sulfate solutions as electrolytes is a very promising strategy to produce environment friendly carbon/carbon supercapacitors, able to reach in the future the targeted energy and power density of organic electrolyte-based systems with acceptable temperature performance.

\section{Acknowledgments}

Q. G. was supported as part of the Fluid Interface Reactions, Structures and Transport (FIRST) Center, an Energy Frontier Research Center funded by the U.S. Department of Energy, Office of Science, Office of Basic Energy Sciences. A portion of this research was conducted at the Center for Nanophase Materials Sciences, which is a DOE Office of Science User Facility. I thank Prof. François Béguin and Dr. Encarnación Raymundo-Piñero for their very fruitful discussion and precious comments. Notice: This manuscript has been authored by UT-Battelle, LLC, under Contract No. DE-AC0500OR22725 with the U.S. Department of Energy. The United States Government retains and the publisher, by accepting the article for publication, acknowledges that the United States Government retains a non-exclusive, paid-up, irrevocable, world-wide license to publish or reproduce the published form of this manuscript, or allow others to do so, for the United States Government purposes. The Department of Energy will provide public access to these results of federally sponsored research in accordance with the DOE Public Access Plan (http://energy.gov/downloads/doe-public-access-plan).

\section{References}

[1] F. Beguin, V. Presser, A. Balducci, E. Frackowiak, Adv Mater, 26 (2014) 2219-2251.

[2] E. Frackowiak, Q. Abbas, F. Beguin, J. Energy Chem., 22 (2013) 226-240.

[3] K. Fic, M. Meller, J. Menzel, E. Frackowiak, Electrochimica Acta, 206 (2016) 496-503.

[4] A. González, E. Goikolea, J.A. Barrena, R. Mysyk, Renewable and Sustainable Energy Reviews, 58 (2016) 1189-1206. 
[5] C. Zhong, Y.D. Deng, W.B. Hu, J.L. Qiao, L. Zhang, J.J. Zhang, Chemical Society Reviews, 44 (2015) 74847539.

[6] Q. Abbas, P. Babuchowska, E. Frąckowiak, F. Béguin, Journal of Power Sources, 326 (2016) 652-659.

[7] M.P. Bichat, E. Raymundo-Pinero, F. Beguin, Carbon, 48 (2010) 4351-4361.

[8] L. Demarconnay, E. Raymundo-Pinero, F. Beguin, Electrochemistry Communications, 12 (2010) 1275-1278.

[9] P. Ratajczak, M.E. Suss, F. Kaasik, F. Béguin, Energy Storage Materials, 16 (2019) 126-145.

[10] K. Fic, G. Lota, M. Meller, E. Frackowiak, Energy \& Environmental Science, 5 (2012) 5842-5850.

[11] Q. Gao, L. Demarconnay, E. Raymundo-Pinero, F. Beguin, Energy \& Environmental Science, 5 (2012) 9611-9617.

[12] M. He, K. Fic, E. Fṛckowiak, P. Novák, E.J. Berg, Energy \& Environmental Science, 9 (2016) 623-633.

[13] Q. Abbas, F. Beguin, Chemsuschem, 11 (2018) 975-984.

[14] X. Li, B.Q. Wei, Nano Energy, 2 (2013) 159-173.

[15] S. Leyva-Garcia, E. Morallon, D. Cazorla-Amoros, F. Beguin, D. Lozano-Castello, Carbon, 69 (2014) 401408.

[16] L. Demarconnay, E. Raymundo-Pinero, F. Beguin, Journal of Power Sources, 196 (2011) 580-586.

[17] J. Zhang, Z. Zhang, Y. Jiao, H. Yang, Y. Li, J. Zhang, P. Gao, Journal of Power Sources, 419 (2019) 99-105.

[18] B. Kirubasankar, V. Murugadoss, J. Lin, T. Ding, M. Dong, H. Liu, J. Zhang, T. Li, N. Wang, Z. Guo, S. Angaiah, Nanoscale, 10 (2018) 20414-20425.

[19] M. Liu, B. Li, H. Zhou, C. Chen, Y. Liu, T. Liu, Chemical Communications, 53 (2017) 2810-2813.

[20] W. Du, X. Wang, J. Zhan, X. Sun, L. Kang, F. Jiang, X. Zhang, Q. Shao, M. Dong, H. Liu, V. Murugadoss, Z. Guo, Electrochimica Acta, 296 (2019) 907-915.

[21] K. Le, Z. Wang, F. Wang, Q. Wang, Q. Shao, V. Murugadoss, W. Liu, J. Liu, Q. Gao, S. Wu, Z. Guo, Dalton Transactions, (2019).

[22] A. Janes, J. Eskusson, L. Mattisen, E. Lust, J. Solid State Electrochem., 19 (2015) 769-783.

[23] Q. Abbas, P. Ratajczak, P. Babuchowska, A.L. Comte, D. Bélanger, T. Brousse, F. Béguin, J. Electrochem. Soc., 162 (2015) A5148-A5157.

[24] Q.T. Qu, B. Wang, L.C. Yang, Y. Shi, S. Tian, Y.P. Wu, Electrochemistry Communications, 10 (2008) 16521655.

[25] K. Jost, C.R. Perez, J.K. McDonough, V. Presser, M. Heon, G. Dion, Y. Gogotsi, Energy \& Environmental Science, 4 (2011) 5060-5067.

[26] X. Wang, Y. Li, F. Lou, M.E. Melands ø Buan, E. Sheridan, D. Chen, RSC Advances, 7 (2017) 23859-23865.

[27] Q. Abbas, F. Beguin, Journal of Power Sources, 318 (2016) 235-241.

[28] D. Weingarth, R. Drumm, A. Foelske-Schmitz, R. Kötz, V. Presser, Physical Chemistry Chemical Physics, 16 (2014) 21219-21224.

Tables 
Table 1 The equivalent distributed resistance (EDR) obtained from Nyquist plots, solvated cation radius, and conductivity at room temperature of $0.5 \mathrm{~mol} \mathrm{~L}^{-1} \mathrm{Li}_{2} \mathrm{SO}_{4}, \mathrm{Na}_{2} \mathrm{SO}_{4}$ and $\mathrm{K}_{2} \mathrm{SO}_{4}$ [24,25].

\begin{tabular}{|c|c|c|c|}
\hline $\begin{array}{l}\text { Aqueous } \\
\text { electrolyte }\end{array}$ & $\begin{array}{l}\text { EDR } \\
(\mathrm{ohm})\end{array}$ & $\begin{array}{c}\text { Solvated cation } \\
\text { radius }(\AA)\end{array}$ & $\begin{array}{l}\text { Conductivity } \\
\left(\mathrm{ms} \mathrm{cm}^{-1}\right)\end{array}$ \\
\hline $\mathrm{Li}_{2} \mathrm{SO}_{4}$ & 6.58 & 3.82 & 45 \\
\hline $\mathrm{Na}_{2} \mathrm{SO}_{4}$ & 4.84 & 3.58 & 54.2 \\
\hline $\mathrm{K}_{2} \mathrm{SO}_{4}$ & 1.80 & 3.31 & 74.6 \\
\hline
\end{tabular}

Table 2 Solubility of alkali sulfates in water at $0{ }^{\circ} \mathrm{C}$ and $25{ }^{\circ} \mathrm{C}$.

\begin{tabular}{ccc}
\hline Aqueous & Solubility & Solubility \\
electrolyte & $\mathrm{mol} \mathrm{L}^{-1}\left(0{ }^{\circ} \mathrm{C}\right)$ & $\mathrm{mol} \mathrm{L}^{-1}\left(25^{\circ} \mathrm{C}\right)$ \\
\hline $\mathrm{Li}_{2} \mathrm{SO}_{4}$ & 3 & 2.7 \\
$\mathrm{Na}_{2} \mathrm{SO}_{4}$ & 0.34 & 1.97 \\
$\mathrm{~K}_{2} \mathrm{SO}_{4}$ & 0.4 & 0.69 \\
\hline
\end{tabular}

Figure captions 
Figure 1. Three-electrode cyclic voltammograms $\left(\mathrm{CVs}, 2 \mathrm{mV} \mathrm{s}{ }^{-1}\right)$ of $\mathrm{AC}$ in (a) $0.5 \mathrm{~mol} \mathrm{~L}^{-1} \mathrm{Li}_{2} \mathrm{SO}_{4}$, (b) $0.5 \mathrm{~mol} \mathrm{~L}^{-1} \mathrm{Na}_{2} \mathrm{SO}_{4}$, and (c) $0.5 \mathrm{~mol} \mathrm{~L}^{-1} \mathrm{~K}_{2} \mathrm{SO}_{4}$. The loops are obtained by stepwise shifting the negative potential limit to more negative values. The vertical line corresponds to the thermodynamic potential for water reduction.

Figure 2. Nyquist plots obtained with symmetric AC/AC capacitors. Electrolytes: $0.5 \mathrm{~mol} \mathrm{~L}^{-1}$ $\mathrm{Li}_{2} \mathrm{SO}_{4}, 0.5 \mathrm{~mol} \mathrm{~L}^{-1} \mathrm{Na}_{2} \mathrm{SO}_{4}$ and $0.5 \mathrm{~mol} \mathrm{~L}^{-1} \mathrm{~K}_{2} \mathrm{SO}_{4}$.

Figure 3. Ragone plots obtained with symmetric AC/AC capacitors working at $1.6 \mathrm{~V}$ applying current densities from 0.2 to $10 \mathrm{~A} \mathrm{~g}^{-1}$. Electrolytes: $0.5 \mathrm{~mol} \mathrm{~L}^{-1} \mathrm{Li}_{2} \mathrm{SO}_{4}, 0.5 \mathrm{~mol} \mathrm{~L}^{-1} \mathrm{Na}_{2} \mathrm{SO}_{4}$ and 0.5 $\mathrm{mol} \mathrm{L}^{-1} \mathrm{~K}_{2} \mathrm{SO}_{4}$.

Figure 4. Nyquist plots of symmetric carbon/carbon capacitors in alkali sulfates at $-10{ }^{\circ} \mathrm{C}$.

Figure 5. Three-electrode cyclic voltammograms (CVs, $2 \mathrm{mV} \mathrm{s}^{-1}$ ) of $\mathrm{AC}$ in $2 \mathrm{~mol} \mathrm{~L}^{-1} \mathrm{Li}_{2} \mathrm{SO}_{4}$ at $20{ }^{\circ} \mathrm{C}$ (a) and $-10{ }^{\circ} \mathrm{C}(\mathrm{b})$. The loops are obtained by stepwise shifting the negative potential limit to more negative values. The vertical line at $-0.35 \mathrm{~V}$ vs. NHE corresponds to the thermodynamic potential for water reduction.

Figure 6. Cyclic voltammograms $\left(2 \mathrm{mV} \mathrm{s}^{-1}\right)$ of symmetric $\mathrm{AC} / \mathrm{AC}$ capacitors obtained at $20{ }^{\circ} \mathrm{C}$ (a) and $-10{ }^{\circ} \mathrm{C}(\mathrm{b})$. Electrolyte: $2 \mathrm{~mol} \mathrm{~L}^{-1} \mathrm{Li}_{2} \mathrm{SO}_{4}$.

Figure 7. Nyquist plots of symmetric AC/AC capacitors in $2 \mathrm{~mol} \mathrm{~L}^{-1} \mathrm{Li}_{2} \mathrm{SO}_{4}$ at 20 and $-10{ }^{\circ} \mathrm{C}$.

Figure 8. Evolution of the discharge capacitance of symmetric capacitors in $2 \mathrm{~mol} \mathrm{~L}^{-1} \mathrm{Li}_{2} \mathrm{SO}_{4}$ during galvanostatic charge-discharge cycling $\left(1 \mathrm{~A} \mathrm{~g}^{-1}\right)$ at $20{ }^{\circ} \mathrm{C}$ and $-10{ }^{\circ} \mathrm{C}$. 
Figure 1
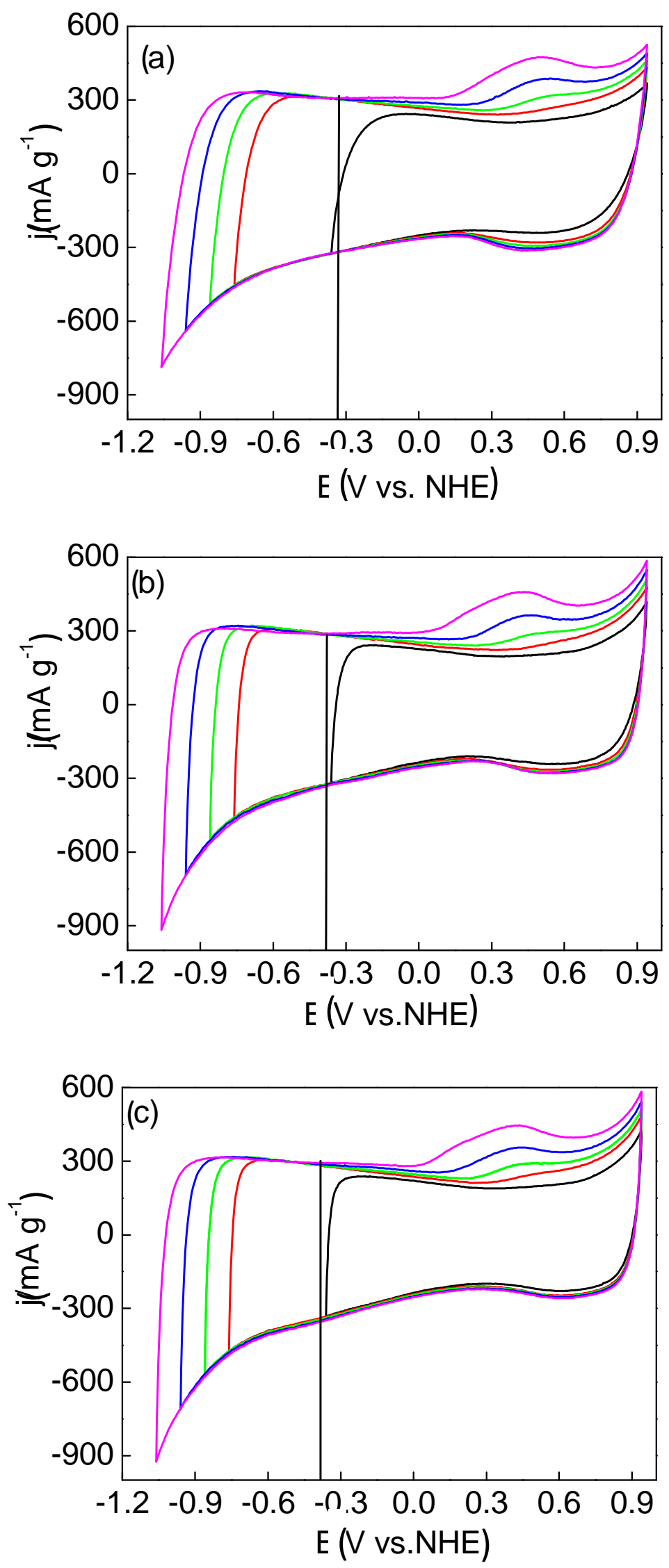
Figure 2

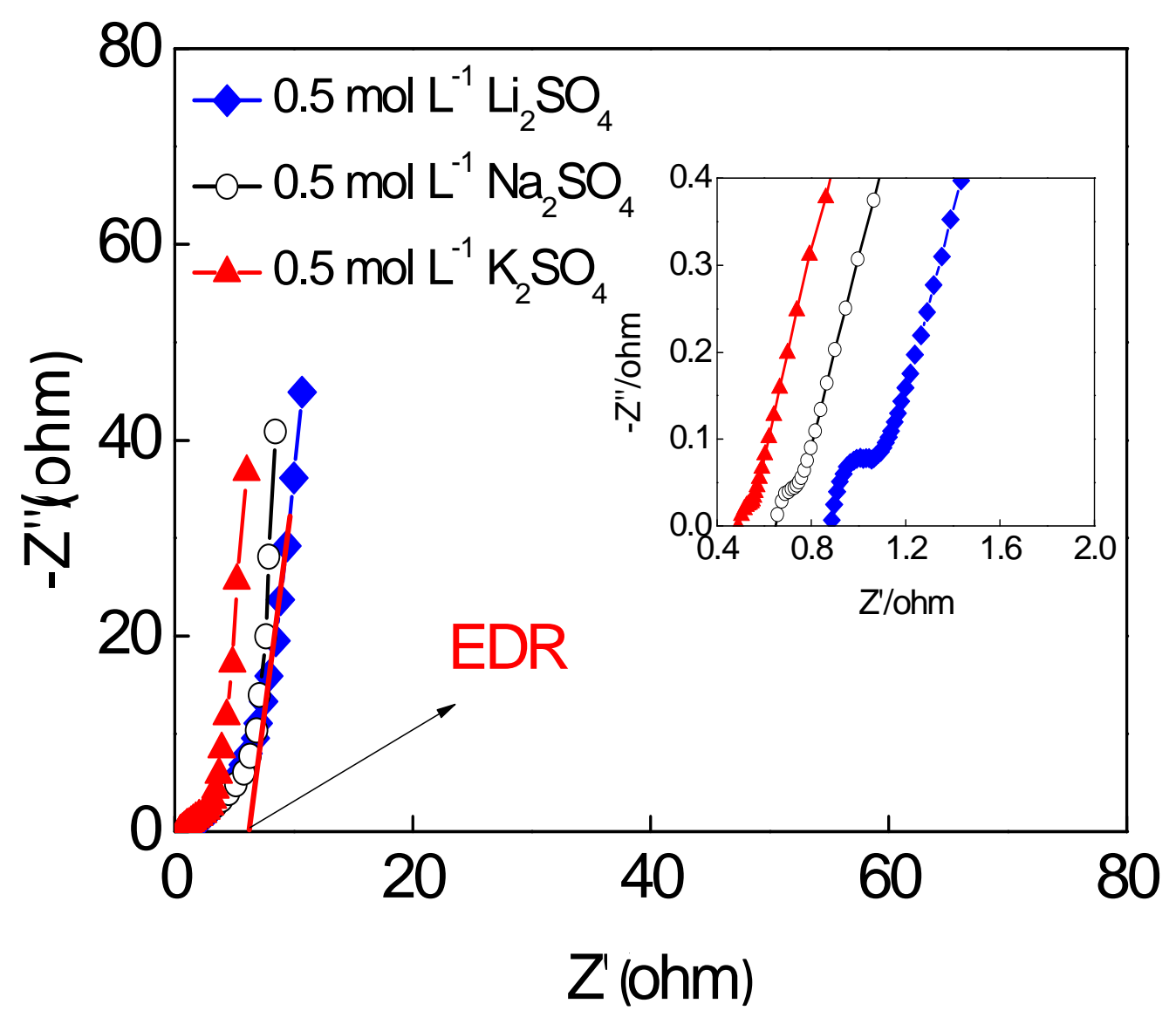


Figure 3

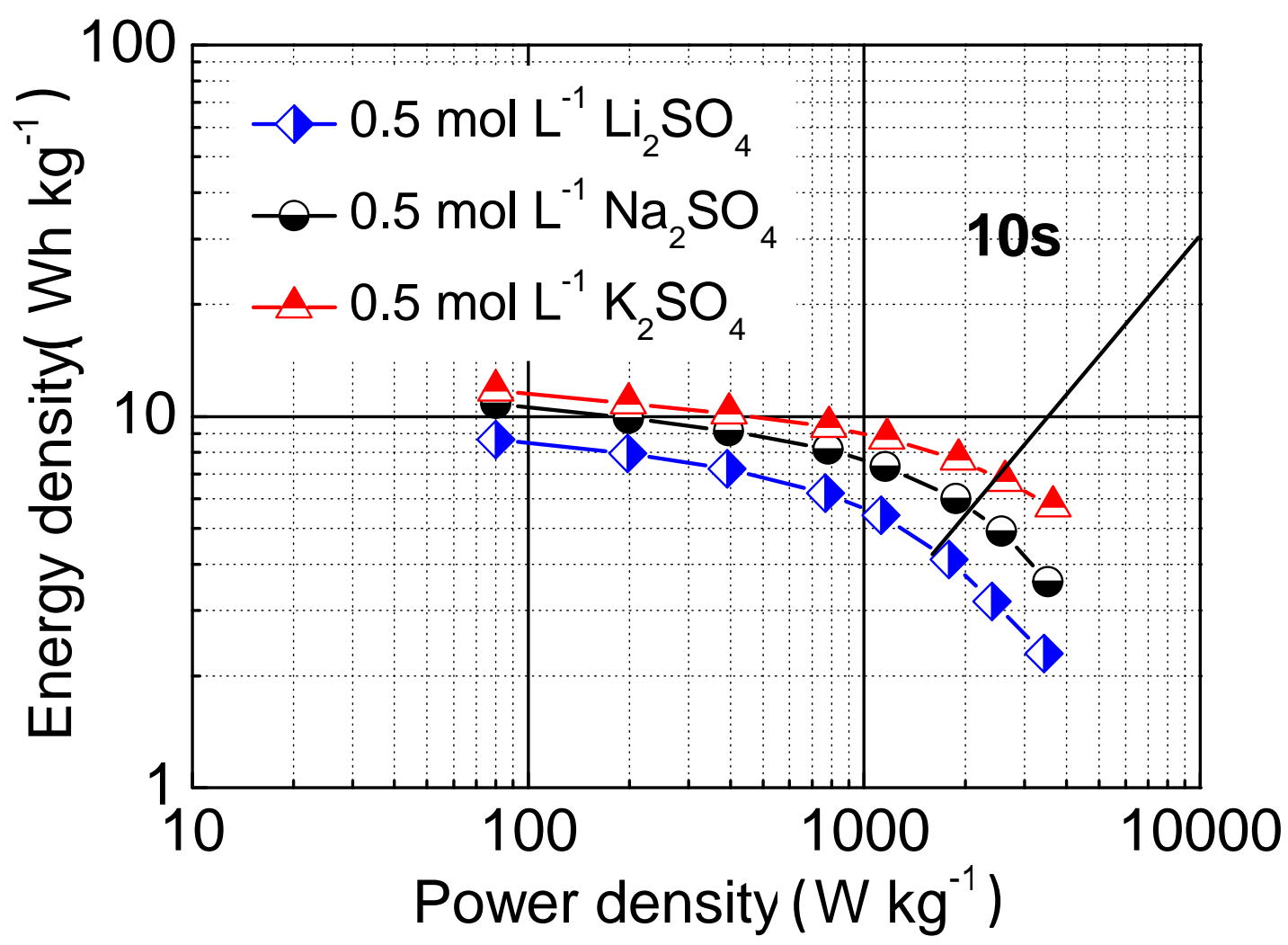


Figure 4

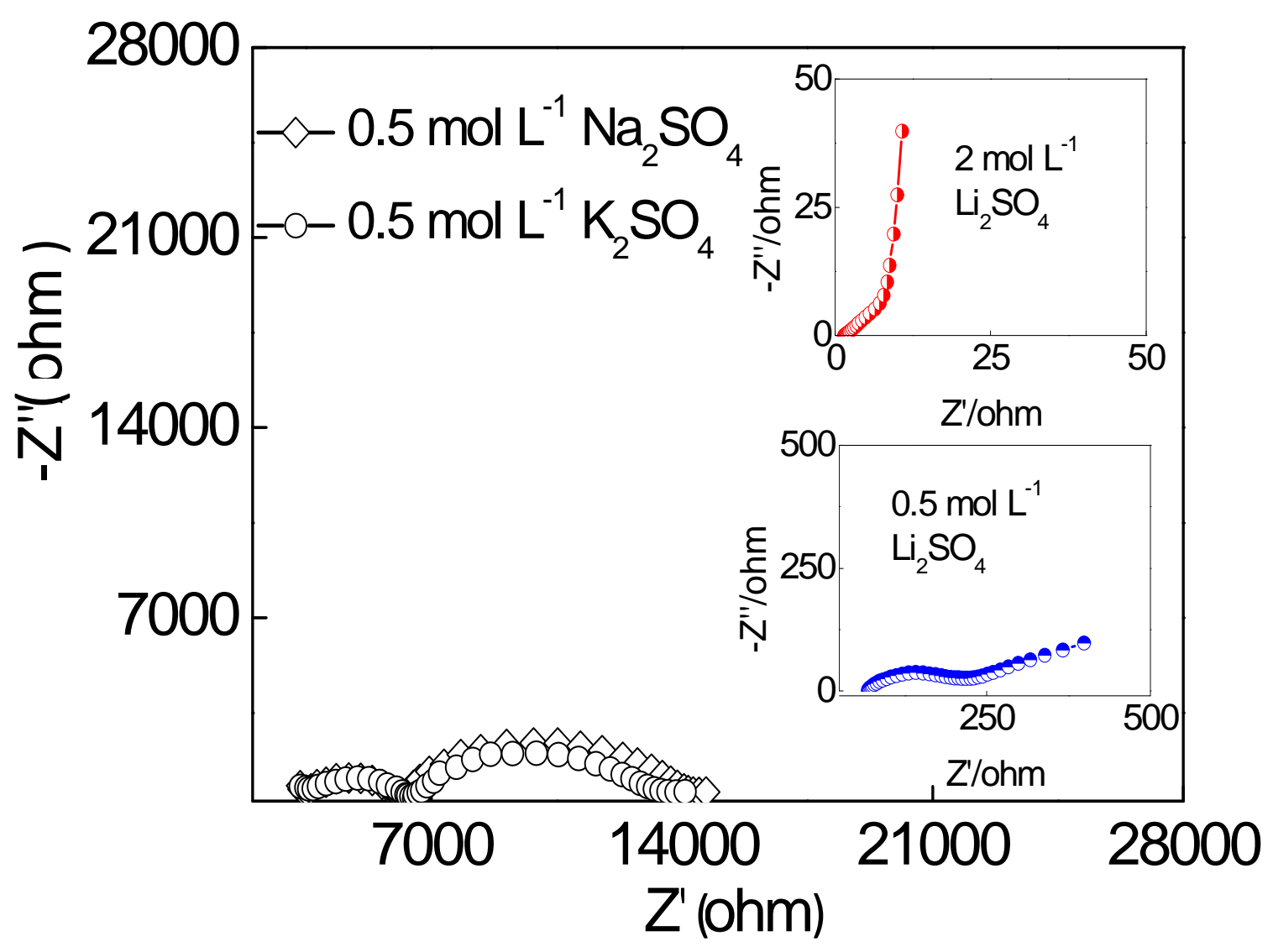


Figure 5
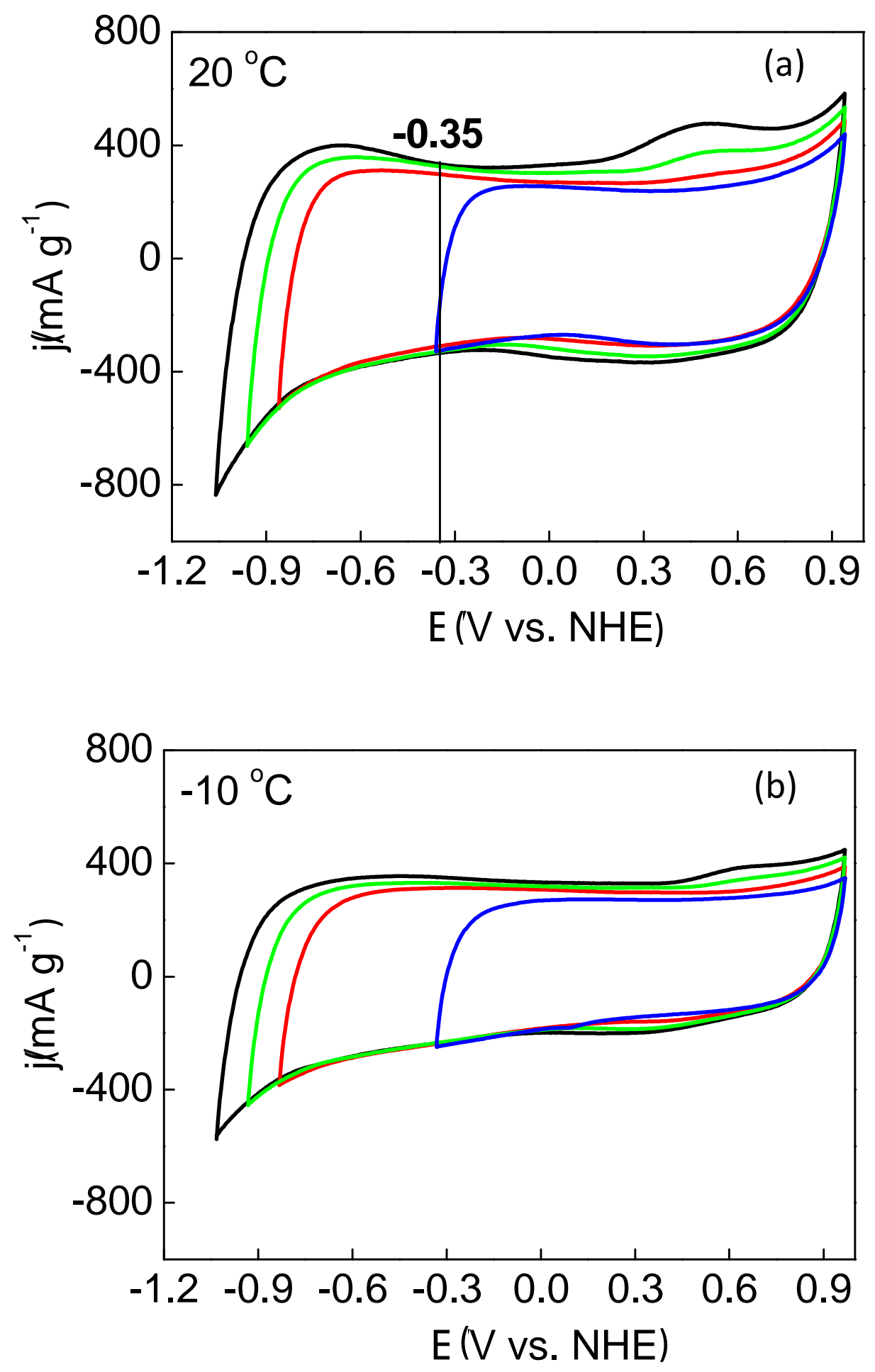
Figure 6
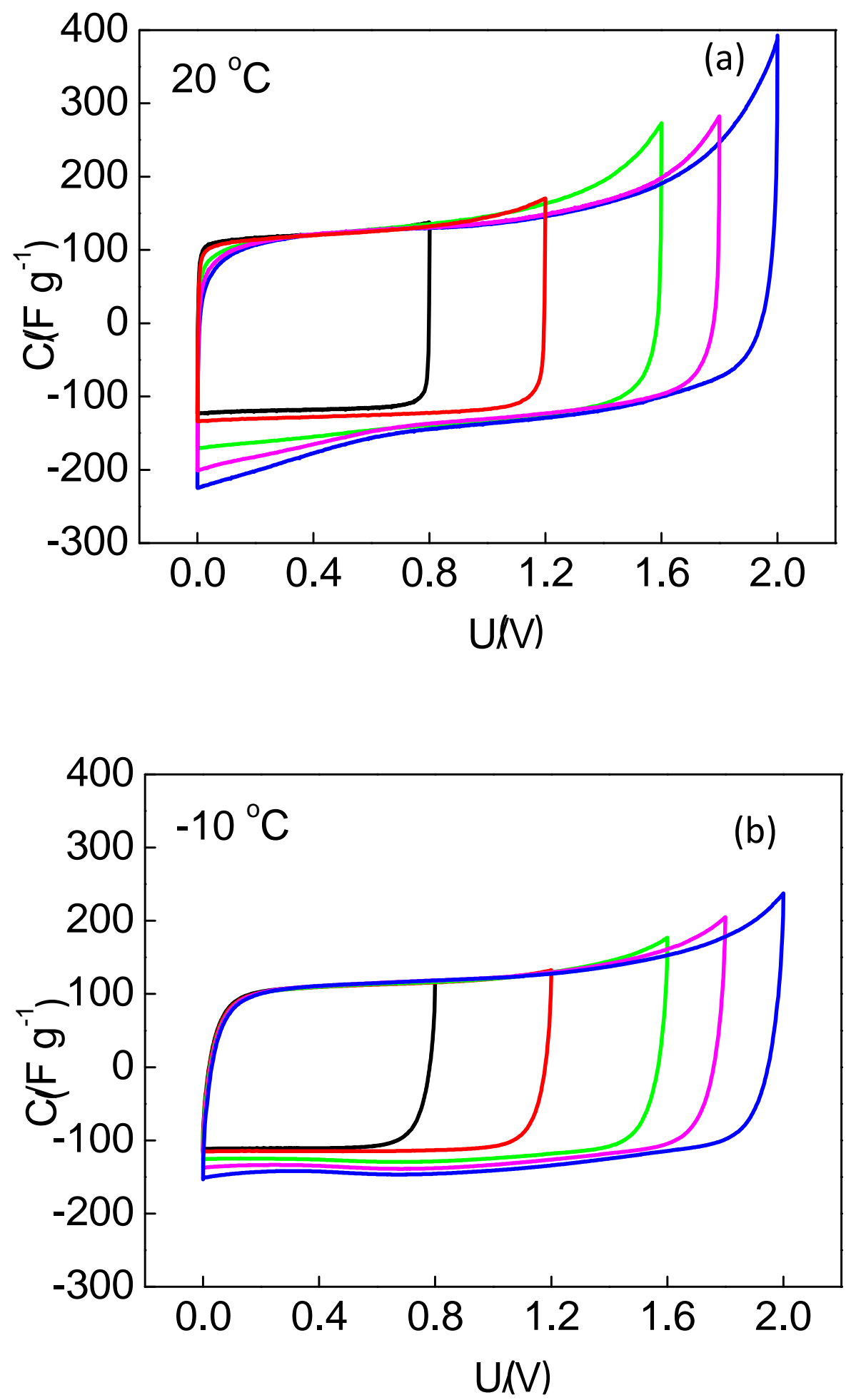
Figure 7

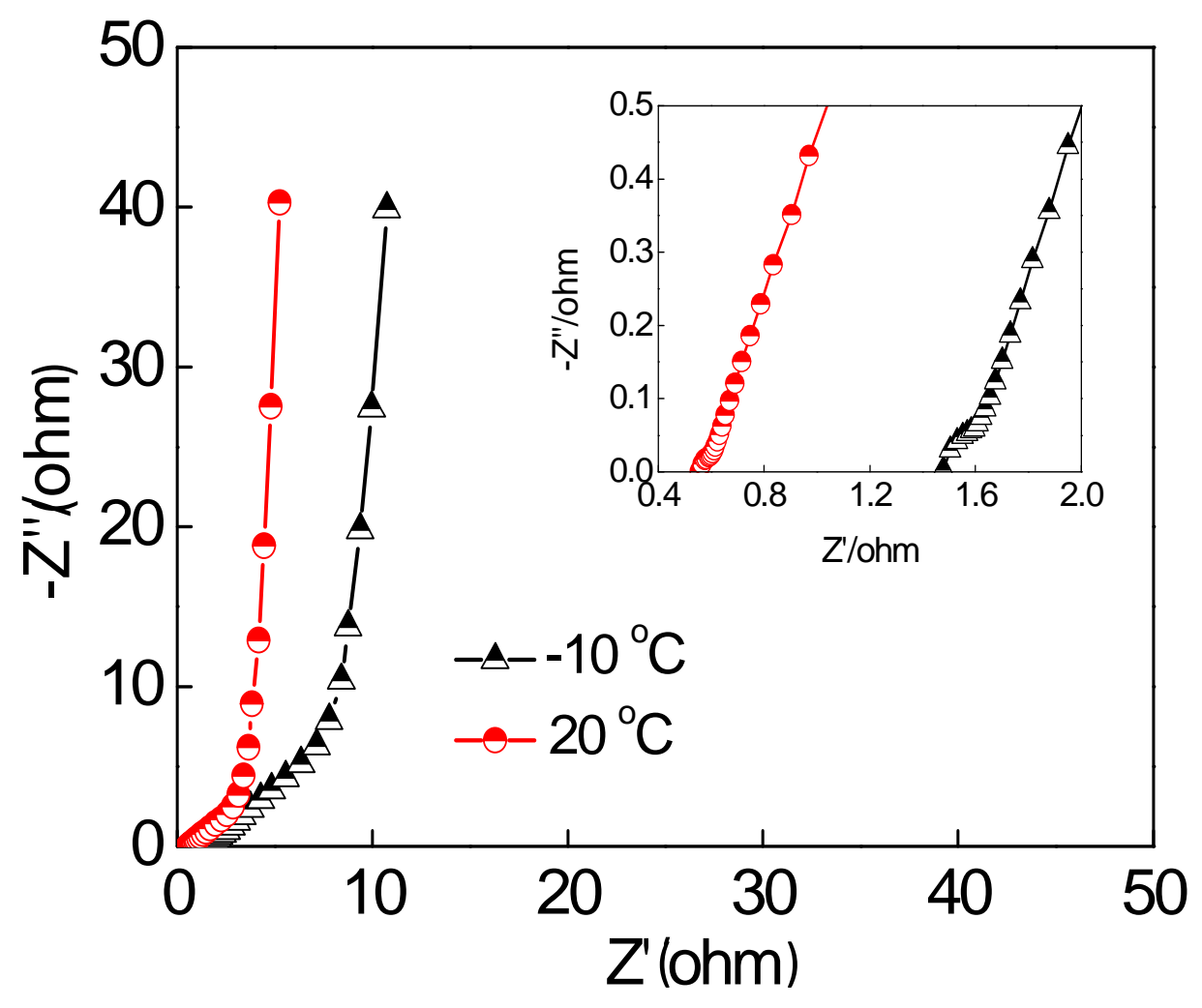


Figure 8

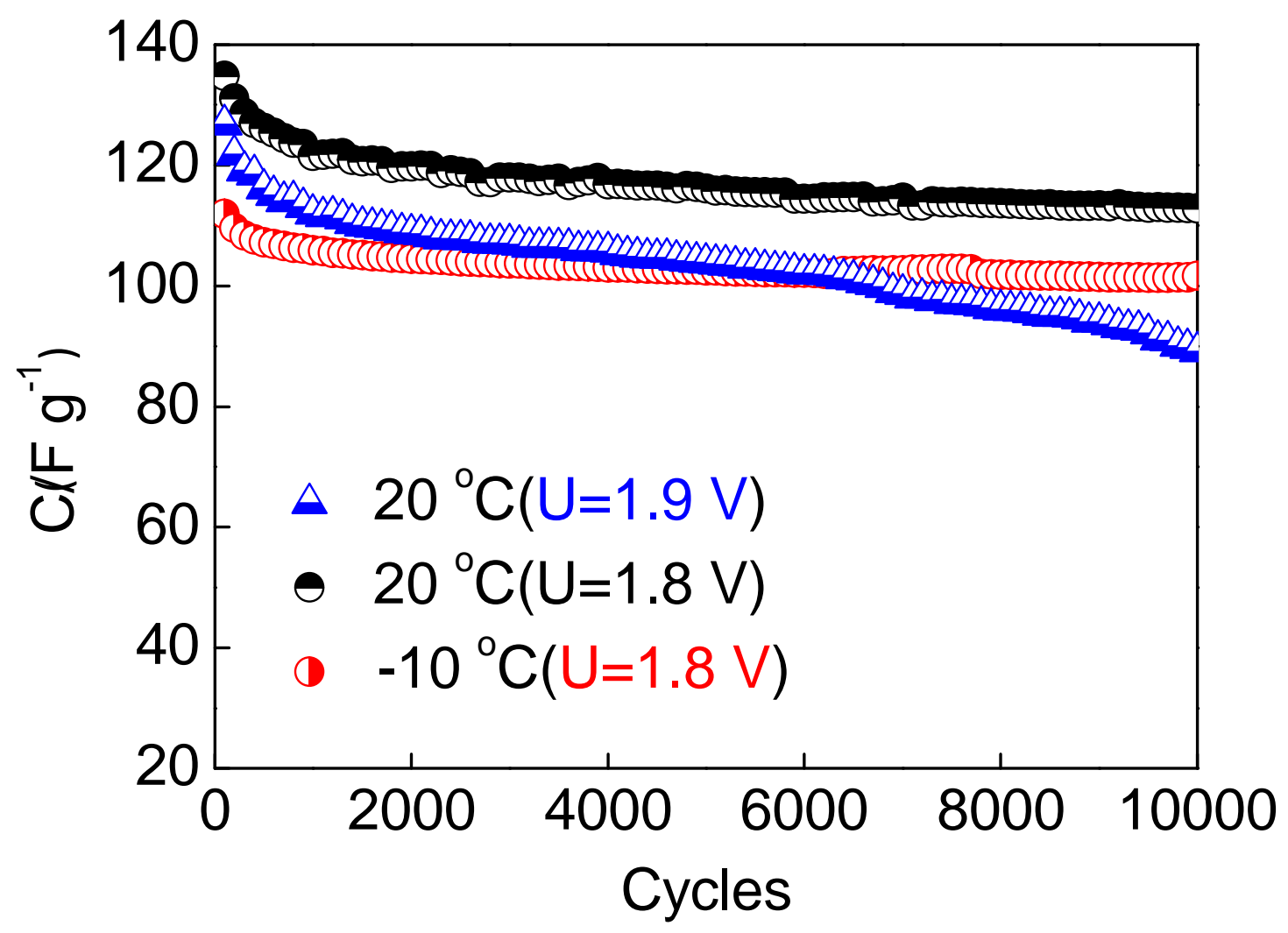


This work highlights the selected virtues of different alkali sulfate electrolytes for enhanced supercapacitors.

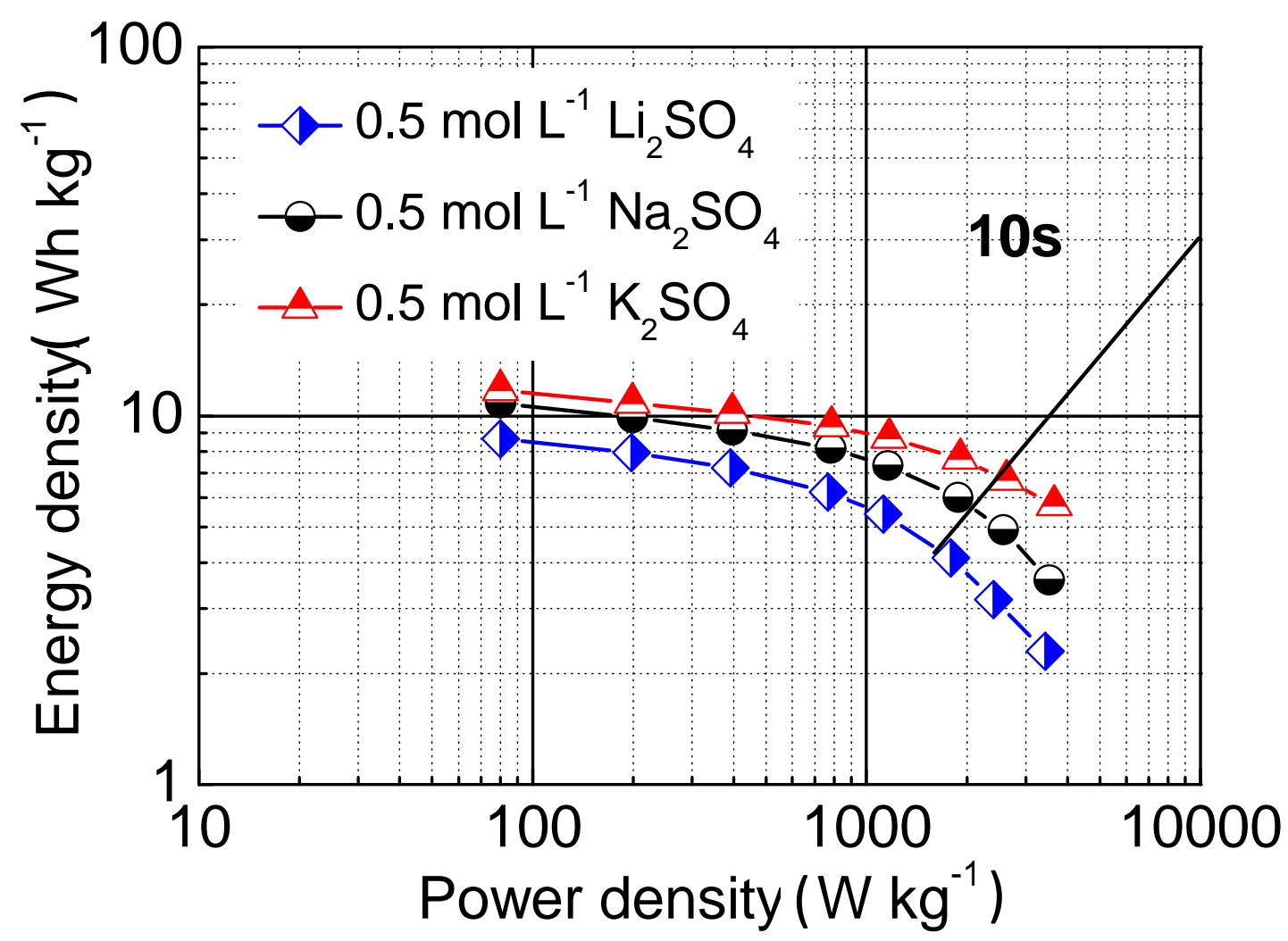

